\title{
LÓDŹ RADIOCARBON DATES II
}

\section{ANDRZEJ KANWISZER and PAWEL TRZECIAK}

Archaeological and Ethnographical Museum in Lódź, 91-415 Lódź. pl Wolności 14, Poland

The following list consists of dates of archaeologic and geologic samples measured from January 1981 to December 1982. Measurements were continued with the same proportional counter system, pretreatment procedure, methane preparation, measurement, and calculation, as described previously (Kanwiszer \& Trzeciak, 1984). Ages were computed on the ${ }^{14} \mathrm{C}$ half-life of $5568 \pm 30$ years. Precision is reported as one standard deviation based only on statistical counting uncertainties in the measurement of the background, NBS modern standard, and sample activities. The dates are not corrected for ${ }^{13} \mathrm{C}$ fractionation. Descriptions and comments are based on information supplied by submitters of samples.

\section{ARCHAEOLOGIC SAMPLES}

\section{LOD-157. Puck}

$1140 \pm 90$

Wood from construction fragment of stave boat found in Puck $\left(54^{\circ} 45^{\prime}\right.$ $\left.\mathrm{N}, 18^{\circ} 20^{\prime} \mathrm{E}\right)$, Gdańsk prov. This boat wreck is important link of boat building evolution in Europe. Iepth $1.20 \mathrm{~m}$, Sec XIV. Sample coll and subm by W Stẹpień, Rescarch and Arts Specification Center, Lódź.

General Comment: ${ }^{14} \mathrm{C}$ age converges with ceramic period.

\section{LOD-158. Kuźnica Skakawska}

$2560 \pm 140$

Wood and charcoal from wattle feature coll during systematic excavation in Kuźnica Skakawska village (51 $\left.16^{\prime} \mathrm{N}, 18^{\circ} 19^{\prime} \mathrm{E}\right)$, Kalisz prov. Sample coll and subm by J Jadczyk, Archacol and Ethnog Mus, Lódź.

LOD-159. Zberzyn 3a

$4720 \pm 110$

Charcoal coll during excavation in Zberzyn village $\left(52^{\circ} 26^{\prime} \mathrm{N}, 18^{\circ} 08^{\prime}\right.$ E), Kohin prov. This site dates from the TRB period. Sample coll from a burned batten which is lying on clayey mud floor of hut under the Kujawian barrow mound no. IV. Depth 0.84m, Plot A3, Level 99.10. Dates building of Kujawian barrows period in Wiórek phase of TRB. Sample coll by K Gorczyca, subm by R Grygiel, Archaeol and Ethnog Mus, Lódź.

\section{Brześć Kujawski series}

Brześć Kujawski is located at confluence of Zgłowiagczka $\mathrm{R}$ and Bachorza R, $\left(52^{\circ} 36^{\prime} \mathrm{N}, 18^{\circ} 35^{\prime} \mathrm{E}\right)$, Włocławek prov. Archaeol research, conducted by K Jażdżewski from 1933-1938, uncovered, close to present town, several sites dating from Neolithic to 13th century. At present these excavations are being continued by $\mathrm{R}$ Grygiel, who is particularly concerned with settlement of Brześć-Kujawian group, mainly of the Lengel culture. ${ }^{14} \mathrm{C}$ dates will be used to date unique complex-Brześć Kujawski. All samples coll and subm by R Grygiel. 
LOD-160. Brześć Kujawski 1/81

Charcoal, NW of Site 4, concentration, lens in Pit 735, depth $1.20 \mathrm{~m}$.

LOD-163. Brześć Kujawski 4/81

$5130 \pm 160$

Charcoal, S of Site 3, lens in Pit 774, depth 2m.

LOD-164. Brześć Kujawski 5/81

$5210 \pm 180$

Charcoal, S of Site 3, lens in Pit 775, depth $2 \mathrm{~m}$.

LOD-165. Brześć Kujawski 6/81

$5370 \pm 180$

Charcoal, S of Site 3, lens in Pit 782, depth $0.80 \mathrm{~m}$.

LOD-166. Brześć Kujawski 7/81

$6490 \pm 350$

Charcoal, S of Site 3, lens in Pit 784, depth $0.70 \mathrm{~m}$.

LOD-167. Brześć Kujawski 8/81

$5410 \pm 340$

Charcoal, S of Site 3, lens in Pit 787, depth $0.60 \mathrm{~m}$.

LOD-168. Brześć Kujawski 9/81

$2460 \pm 80$

Charcoal, SE of Site 3, lens in Pit 806, depth $1.20 \mathrm{~m}$.

LOD-169. Brześć Kujawski 10/81

$4100 \pm 150$

Charcoal, S of Site 3, lens in Pit 809, depth $0.90 \mathrm{~m}$.

LOD-170. Brześć Kujawski 11/81

$4930 \pm 170$

Charcoal, E of Site 3, lens in Pit 816, depth $0.70 \mathrm{~m}$.

LOD-171. Brześć Kujawski 12/81

$2460 \pm 100$

Charcoal, W of Site 3, lens in Pit 823, depth $0.50 \mathrm{~m}$.

LOD-172. Brześć Kujawski 13/81

Charcoal, E of Site 3, lens in Pit 825, depth $0.60 \mathrm{~m}$.

$6490 \pm 460$

LOD-173. Brześć Kujawski 14/81

$5250 \pm 180$

Charcoal, W of Site 3, lens in Pit 834, depth $0.70 \mathrm{~m}$.

LOD-187. Brześć Kujawski 4/82

$5280 \pm 190$

Charcoal, Site 4, lens in Pit 899, depth $1.20 \mathrm{~m}$.

LOD-188. Brześć Kujawski 1/82

$6400 \pm 220$

Charcoal, Site 4, fire layer, carbonized beam, in transverse ditch of Hut 56 , depth $0.80 \mathrm{~m}$.

LOD-193. Brześć Kujawski 2/82

$5400 \pm 190$

Charcoal, Site 4, lens at base of Pit 892, depth 0.60 to $0.80 \mathrm{~m}$.

LOD-194. Brześć Kujawski 2/83

$5280 \pm 190$

Charcoal, Site 4 , lens in ditch of Hut 56 , depth ca $1 \mathrm{~m}$. 
LOD-195. Brześć Kujawski 1/83

Charcoal, Site 4 , lens at base of Pit 893 , depth $1.8 \mathrm{~m}$.

\section{LOD-174. Gustorzyn 1}

Charcoal from Gustorzyn $\left(52^{\circ} 36^{\prime} \mathrm{N}, 18^{\circ} 35^{\prime} \mathrm{E}\right)$, Włocławek prov, coll from fill of hut-type dwelling which dates from Lengyel cultural period; depth 0.50 to $0.60 \mathrm{~m}$. This is earliest date from Lengyel culture. Sample coll and subm by R Crygicl.

\section{LOD-175. Dabrówno}

$610 \pm 70$

Charcoal from burned feature of construction of Teutonic Knights' castle. Castle and Iabrówno town $\left(53^{\circ} 25^{\prime} \mathrm{N}, 20^{\circ} 02^{\prime} \mathrm{E}\right)$, (Olsztyn prov, are on isthmus between two lakes. Sample coll and subm by A Nadolski, Inst Hist Material Culture, Polish Acad Sci, Xódź.

LOD-178. Wawolnica

$5070 \pm 210$

Charcoal from Wawolnica $\left(51^{\circ} 28^{\prime} \mathrm{N}, 22^{\circ} 06^{\prime} \mathrm{E}\right)$, Lublin prov, coll during systematic excavation. Dating material was scattered in pit, at $1.60 \mathrm{~m}$ depth from surface. It probably dates from Volhyn-Lublin Painted Pottery cultural period. Sample coll and subm by A Zakościelna, Inst Archaeol, Lublin Univ, Lublin.

\section{Turowiec and Mecikał series}

Four charcoal samples, 2 from Turowiec village $\left(52^{\circ} 50^{\prime} \mathrm{N}, 18^{\circ} 10^{\prime} \mathrm{E}\right)$, 2 from Mecikał village $\left(52^{\circ} 50^{\prime} \mathrm{N}, 18^{\circ} 15^{\prime} \mathrm{E}\right)$, Bydgoszcz prov. Dates should help establish chronology of Late-Komornik inventories of Kashube lake district. Samples coll and subm by Z Bagniewski, Archaeol Dept, Wrocław Univ, Wrocław.

LOD-179. Turowiec T-1-p-2

$3920 \pm 200$

Charcoal from hearth surrounded by stone; depth 0.40 to $0.46 \mathrm{~m}$.

LOD-180. Mescikał M-6-p-3/79

$5780 \pm 260$

Charcoal from free-standing hearth surrounded by stone.

LOD-181. Turowiec T-3-p-1

$4110 \pm 200$

Charcoal from partly scattered hearth surrounded by stone.

LOD-182. Mẹcikał M-11-k-1

$4860 \pm 210$

Scattered charcoal from concentration of flint artifacts no. 1, buried in the floor trough.

\section{Saidiya series}

Two samples, probably carbonized food, from Saidiya $\left(34^{\circ} \mathrm{N}, 45^{\circ} \mathrm{E}\right)$, near Jalaula town in NE Iraq. Samples were composed of carbonized organic substance, concentrated on floor, in disturbed cultural layer, around hearth, with ceramic and stone artifacts in situ (pieces from inside 
jugs). Depth from surface: 0.60 to $0.75 \mathrm{~m}$. Dates help determine real age of site, and have already shed new light on prehistory of Mesopotamian region. Samples coll and subm by S K Kozłowski.

\section{LOD-183. Saidiya 1}

$6070 \pm 270$

Carbonized food.

LOD-184. Saidiya 2

$5780 \pm 260$

Carbonized food.

\section{LOD-185. Kochlew 1/7}

$7490 \pm 220$

Wood coll during systematic excavation in Kochlew village $\left(51^{\circ} 12^{\prime} \mathrm{N}\right.$, $\left.18^{\circ} 42^{\prime} \mathrm{E}\right)$, Sieradz prov. Sample was composed of small fragments scattered in peat layer, at depth 0.30 to $0.40 \mathrm{~m}$ from surface. Dated to determine chronology of second terrace surface. Sample coll and subm by K Cyrek, Archacol and Ethnog Mus, Lódź.

General Comment: both archaeologic and geologic excavations were conducted at the same time by K Cyrek and P Marosik at Kochlew. Description and more dates of archacologic and geologic samples were pub earlier (Kanwiszer \& Trzeciak, 1984).

\section{Lykowe series}

This series is a continuation of archacologic dates from site in Lykowe village $\left(51^{\circ} 12^{\prime} \mathrm{N}, 18^{\circ} 47^{\prime} \mathrm{E}\right)$, Sieradz prov. Systematic excavations were conducted by M Cyrek and K Cyrek. Samples were coll and subm by K Cyrek. Detailed description of site with first Lykowe series was pub earlier (Kanwiszer \& Trzeciak, 1984).

LOD-192. Lykowe $1 / 82 / 1$

$4240 \pm 160$

Wood and peat from layer which is remains of wooden footbridge from so-called "excavation near pond" at depth $1.50 \mathrm{~m}$.

LOD-198. Lykowe $1 / 82 / 2$

$5750 \pm 160$ $1.50 \mathrm{~m}$.

Fragment of wooden beam from "excavation near pond" at depth

\section{LOD-199. Lykowe $1 / 82 / 5$}

$5550 \pm 150$

Charcoal from hearth within dwelling feature from VII $/ 0_{20}(-20)$ at depth 0.40 to $0.80 \mathrm{~m}$.

LOD-200. Lykowe 1/82/6

$5300 \pm 150$ $0.80 \mathrm{~m}$.

Charcoal from grate pit (or cultural pit) from X/0 $0_{23}(-50)$ at depth

LOD-201. Lykowe $1 / 82 / 9$

$5480 \pm 140$ $0.80 \mathrm{~m}$.

Charcoal from domestic pit from XI/ $0_{20}(-40)$ at depth 0.60 to 
LOD-202. Lykowe $1 / 83 / 4$ $0.80 \mathrm{~m}$

Charcoal from grate pit (or cultural pit) from X/0 $0_{23}(-50)$ at depth

LOD-203. Krzeczów 2/83

$4250 \pm 140$

Charcoal from archaeologic site in Krzeczów (51 $\left.09^{\prime} \mathrm{N}, 18^{\circ} 46^{\prime} \mathrm{E}\right)$, Sieradz prov. Sample from grate pit, at depth $1 \mathrm{~m}$ from A/a $(-100)$; coll and subm by K Cyrek.

\section{Mały Płock series}

Two samples of charcoal from Mały Płock ( $\left.53^{\circ} 18^{\prime} \mathrm{N}, 22^{\circ} 02^{\prime} \mathrm{E}\right)$, Lomża prov. Dated to establish chronology of Early Middle Ages settlement complex and also to determine chronologic associations within complex. Samples coll by W Wróblewski and J Wysocki; subm by E Tworowska, Archaeol Inst, Warsaw Univ, Warsaw.

LOD-205. Mały Płock 1c/79

$820 \pm 110$

Burned matter from cultural layer near hearth from Feature 2, NS 20.90-21.18; WE 123.80-124.08 at depth ca $1 \mathrm{~m}$.

LOD-206. Mały Płock 5c/82

$820 \pm 100$

Charcoal from layer of burned matter from settlement Feature 76 , Quarter SOW, WE 42.50 ; NS 56.85 at depth $0.50 \mathrm{~m}$.

\section{LOD-207. Czerchów}

$670 \pm 100$

Charcoal coll during systematic excavation in Czerchów $\left(51^{\circ} 55^{\prime} \mathrm{N}, 19^{\circ}\right.$ $15^{\prime}$ E), Lódź prov from Hearth 1 , Excavation I, Sec 3 at depth 1.20 to $1.30 \mathrm{~m}$. Sample coll and subm by A Chmielowska, Archaeol and Ethnog Mus, Lódź.

\section{LOD-211. Krzemionki 1}

$5800 \pm 170$

Charcoal from stripped flint mine in Krzemionki $\left(50^{\circ} 59^{\prime} \mathrm{N}, 21^{\circ} 30^{\prime} \mathrm{E}\right.$ ), Kielce prov. Sample coll from area of hearth remains, under shaft dump $6 / 668$ (Krukowski, 1939). Dated to establish chronology of flint workshop under shaft dump. Sample from Ar B 10, Quarter A, m 2, Sec b at depth $0.90 \mathrm{~m}$. Coll and subm by M Zalewski, Natl Archaeol Mus, Warsaw.

GEOLOGIC SAMPIES

\section{Kochlew series}

Peat from Kochlew $\left(51^{\circ} 12^{\prime} \mathrm{N}, 18^{\circ} 48^{\prime} \mathrm{E}\right.$ ), Sieradz prov coll and subm by P Marosik, Archacol and Ethnog Mus, Lódź.

General Comment: archaeologic and geologic excavations were conducted at Kochlew site at same time by P Marosik and K Cyrek. Archacologic dates were reported above.

LOD-176. Kochlew 4/80

$11,950 \pm 270$

Peat from layer between medium-sand with some coarse-sand and silty muck at depth 3.55 to $4.05 \mathrm{~m}$. 
LOD-177. Kochlew 5/80

$12,020 \pm 280$ $4.80 \mathrm{~m}$.

Peat from layer between silty muck and medium-sand at depth 4.55 to

\section{WBM series}

Samples coll from geologic sites in Wola Branicka-Kol $\left(51^{\circ} 57^{\prime} \mathrm{N}, 19^{\circ}\right.$ $27^{\prime} \mathrm{E}$ ), Lódź prov. Dates should help establish chronology of Holocene sediments in river valleys. Samples coll and subm by $\mathrm{H}$ Klatkowa and J Kamiński, Inst Geog, Lódź Univ.

LOD-186. WBM II/41

$7000 \pm 190$

Wood, depth $0.90 \mathrm{~m}$.

LOD-197. WBM II/40

$1900 \pm 110$

Charcoal, depth $1.10 \mathrm{~m}$.

LOD-212. WBM 3-S

$4620 \pm 140$

Sand and organic slime with wood fragments coll from layer within fossil meander at depth $0.80 \mathrm{~m}$.

LOD-213. WBM 4-S

$5730 \pm 140$ $2.10 \mathrm{~m}$

Sand with organics and many wood fragments at depth 1.80 to

\section{LOD-189. Sulejów Piaski 1}

$1660 \pm 90$

Wood (probably fragment of trunk) from Sulejów Piaski $\left(51^{\circ} 22^{\prime} \mathrm{N}\right.$, $19^{\circ} 21^{\prime} \mathrm{E}$ ), Piotrków Trybunalski prov. Sample coll by coring layer of peaty sand with silt at depth 2.0 to $2.2 \mathrm{~m}$. Sample coll and subm by P Marosik.

\section{LOD-190. Srebrna (Todoranka) 1}

$2660 \pm 100$

Sample coll from profile of lacustrine sediment, Srebrna Lake, in Nature Preserve near Srebrna village $\left(44^{\circ} 05^{\prime} \mathrm{N}, 27^{\circ} 05^{\prime} \mathrm{E}\right.$ ), west of town of Silistra, Bulgaria. Sample was composed of scattered peat with admixture of very small mineral fragments with detritus and larger plant fragments. Sample coll by coring at depth $1.90 \mathrm{~m}$. "Srebrna 1" is first profile along Bulgarian section of Danube Valley (Straszewska, 1974). Research of Danube Valley is conducted by Inst Geol Sci, Polish Acad Sci in collaboration with Bulgarian Acad Sci. Sample coll by E Bozikowa, Sofia Univ, Bulgaria and K Straszewska, Inst Geol Sci, Polish Acad Sci, Warsaw.

LOD-191. Rośle 7

$12,000 \pm 420$

Peat coll from layer under dune in Rośle Nowe near Dạbic $\left(52^{\circ} 08^{\prime} \mathrm{N}\right.$, $18^{\circ} 29^{\prime} \mathrm{E}$ ), Konin prov. Sample from base of excavation, at tip of $\mathrm{S}$ arm of dune at depth $4.10 \mathrm{~m}$. Dated to confirm previous ${ }^{14} \mathrm{C}$ dates, LOD- $29,-37$, -40. Series of dates from Rośle Nowe excavation should provide new data on plants and climate during Böling Interstadial (Wasylikowa, 1964). Sample coll by K Krajewski and Z Balwierz; subm by K Krajewski, Inst Geog, Lódź Univ. 


\section{Bychlew series}

Two samples from Bychlew village ( $\left.51^{\circ} 37^{\prime} \mathrm{N}, 19^{\circ} 21^{\prime} \mathrm{E}\right)$, Lódź prov. Both samples were taken during construction drilling. Dated to establish border between Holocene and Pleistocene sediments in valleys. Samples coll and subm by H Klatkowa, Inst Geog, Lódź. Univ.

LOD-196. Bychlew 11/5

$12,000 \pm 300$

Peat, depth $1.65 \mathrm{~m}$.

LOD-210. Bychlew 11/24

$14,400 \pm 300$

Organic ooze, depth $4.50 \mathrm{~m}$.

\section{Bẹdzyn series}

Two samples from site in Besdzyn village $\left(51^{\circ} 13^{\prime} \mathrm{N}, 19^{\circ} 53^{\prime} \mathrm{E}\right)$, Piotrków Trybunalski prov, coll from natural exposure. Dated to establish relation between evolution of Pilica $\mathrm{R}$ valley and prehistoric settlement. Samples coll and subm by $\mathrm{P}$ Marosik.

\section{LOD-204. Bedzyn 3}

$3050 \pm 160$

Wood from layer of sand and organic ooze at depth $1.1 \mathrm{~m}$.

LOD-218. Bẹdzyn 6

$5730 \pm 160$

Charcoal, remains of trunk in layer of river mud at depth $1.7 \mathrm{~m}$.

\section{Dabrówka series}

Two charcoal samples coll from exposure in Dạbrówka Wielka near Brzeziny $\left(51^{\circ} 51^{\prime} \mathrm{N}, 19^{\circ} 43^{\prime} \mathrm{E}\right)$, Skierniewice prov. Samples are from hearths covered with loess sediments, spread across gully. Dated to establish beginning of gully erosion. Samples coll by J Wieczorkowska and subm by J Kamiński.

\section{LOD-208. Dabrówka 13}

$4650 \pm 160$

Charcoal in mineral material from lowest layer of three superimposed hearths from NW wall, depth ca $0.9 \mathrm{~m}$.

\section{LOD-209. Dabrówka 14}

$3500 \pm 160$

Charcoal from highest layer of three superimposed hearths, from NW wall, depth ca $0.7 \mathrm{~m}$.

\section{Paskrzyn and Leg Reçzýnski series}

Three samples from Paskrzyn (51 $14^{\prime} \mathrm{N}, 19^{\circ} 52^{\prime} \mathrm{E}$ ), Piotrków Trybunalski prov, and one from Kegg Rẹczyński $\left(51^{\circ} 14^{\prime} \mathrm{N}, 19^{\circ} 13^{\prime} \mathrm{E}\right)$, Piotrków Trybunalski prov. Dated to establish changes of river channel configurations at base of Pilica R Valley near Przedbórz. All samples coll and subm by P Marosik.

LOD-214. Paskrzyn 1

$2970 \pm 160$

Humus of fossil soil, depth $1.5 \mathrm{~m}$. 
LOD-215. Paskrzyn 2

Charcoal, depth ca $8.0 \mathrm{~m}$.

LOD-216. Lẹg Rẹczyński

er channel), depth $1.8 \mathrm{~m}$.

\section{LOD-217. Paskrzyn 5}

$7360 \pm 170$ cover.

Wood fragment coll from organic oozy layer (floor), under eolian sand

\section{LOD-219. Lublinek}

$9870 \pm 190$

Wood from foundation trench many meters long, at base of Ner R valley, connected with building of waste-water treatment plant, Lublinek near Lódź, (51 $\left.44^{\prime} \mathrm{N}, 19^{\circ} 21^{\prime} \mathrm{E}\right)$, Lódź prov. Sample was chosen among different size branches and a trunk scattered within river sands and river oozes. Sample from $0.5 \mathrm{~m}$ above bottom of lowest flood series, depth $1.7 \mathrm{~m}$. Dated to establish period of strong lateral erosion of Ner R, which precedes period of better stabilization of river channel in center of valley (Turkowska, in press). Sample coll and subm by K Turkowska, Inst Geog, Lódź Univ.

\section{REFERENCES}

Kanwiszer, A and Trzeciak, P, 1984, LODZ radiocarbon dates I: Radiocarbon, v 26, p 111 126.

Krukowski, S, 1939, Krzemionki Opatowskie: Warszawa.

Straszewska, K, 1974, Geneza terasu zalewowego dolnego Dunaju na odcinku Widin-Swisztow, półn. Bułgaria: Studia Geol Polon, v 43.

Turkowska, K, in press, Osady dna doliny Neru w Lublinku k/Xodzi: Acta Geog Lodz, v 50

Wasylikowa, K, 1964, Roślinność i klimat późnego glacjału w Srodkowej Polsce na podstawic badań w Witowie kơo Xẹczycy: Perygl Biul, v 1 . 